Pesq. Vet. Bras. 26(1):51-54, jan./mar. 2006

\title{
Immunoprophylactic strategies against enterotoxemia caused by Clostridium perfringens type $D$ in goats ${ }^{1}$
}

\author{
Josir Laine A. Veschi ${ }^{2}$, Iveraldo S. Dutra ${ }^{3}$, Mariano E. Fernandez Miyakawa ${ }^{4}$, \\ Silvia Helena V. Perri ${ }^{3}$ and Francisco A. Uzal ${ }^{4}$
}

\begin{abstract}
Veschi J.L.A., Dutra I.S., Miyakawa M.E.F., Perri S.H.V. \& Uzal F.A. 2006. Immunophrophylactic strategies against enterotoxemia caused by Clostridium perfringens type D in goats. Pesquisa Veterinária Brasileira 26(1):51-54. Departamento de Produção e Saúde Animal, Universidade Estadual Paulista, Rua Clóvis Pestana 793, Araçatuba, SP 16050-680, Brazil. Email: isdutra@fmva.unesp.br

The serological response to an experimental vaccine against Clostridium perfringens type D enterotoxemia was evaluated in four groups of goats. Group 1 received colostrum from unvaccinated cows and no vaccine. Groups 2, 3 and 4 received colostrum from vaccinated cows. In addition, Groups 3 and 4 received a vaccine dose at 80 days of age, and Group 4 received a second vaccine dose at 120 days of age. Serum antibody levels were determined by ELISA in cows before and after calving, and in goats at 3,80,120 and 160 days of age. No significant difference in serum antibody levels was observed between vaccinated and unvaccinated cows, or between the four groups of goats evaluated at 3 days of life. Groups 3 and 4 presented mean antibody titers of 0.6 and $1.1 \mathrm{IU} /$ $\mathrm{ml}$, respectively, 40 days after first vaccination. The vaccine response of Group 4 was $1.8 \mathrm{IU} / \mathrm{ml} 40$ days after the booster dose and was higher than that observed for Group $3(0.2 \mathrm{IU} / \mathrm{ml})$. Thus, in the proposed regimen the use of heterologous colostrum did not induce passive immunization in goat kids. However, first vaccination and a booster dose after 40 days triggered satisfactory antibody levels.
\end{abstract}

INDEX TERMS: Clostridium perfringens type D, goat, enterotoxemia, immunoprophylactic strategies, colostrum, vaccine.

\begin{abstract}
RESUMO.- [Estratégias imunoprofiláticas contra enterotoxemia causada por Clostridium perfringens tipo D em caprinos.] Foi avaliada a resposta sorológica de vacina experimental contra a enterotoxemia em quatro grupos de caprinos. O Grupo 1 recebeu colostro de vacas não vacinadas e nenhuma dose de vacina. Os Grupos 2, 3 e 4 receberam colostro de vacas vacinadas, e uma dose de vacina aos 80 dias de idade nos Grupos 3 e 4. O Grupo 4 recebeu a segunda dose de vacina aos 120 dias de idade. Os níveis de anticorpos séricos foram avaliados pelo ELISA nas vacas antes e depois do parto e nos caprinos aos 3, 80, 120
\end{abstract}

\footnotetext{
${ }^{1}$ Received on September 2, 2005.

Accepted for publication on November 10, 2005.

${ }^{2}$ Curso de Pós-graduação em Medicina Veterinária Preventiva, FCAV, Universidade Estadual Paulista (Unesp), Prof. Paulo Donato Castellane s/n, Jaboticabal, SP 14884-900, Brazil.

${ }^{3}$ Depto Produção e Saúde Animal, Curso de Medicina Veterinária, Unesp, Rua Clóvis Pestana 793, Araçatuba, SP 16050-680, Brazil. *Author for correspondence. E-mail: isdutra@fmva.unesp.br

${ }^{4}$ California Animal Health and Food Safety, School of Veterinary Medicine, University of California, Davis, San Bernardino, CA, USA.
}

e 160 dias de idade. Não houve diferença significativa nos níveis de anticorpos séricos das vacas vacinadas e não vacinadas, assim como entre os quatro grupos de caprinos avaliados aos três dias de vida. Os Grupos 3 e 4 apresentaram títulos médios de anticorpos de $0,6 \mathrm{UI} / \mathrm{mL}$ e $1,1 \mathrm{UI} / \mathrm{mL}$, respectivamente, aos 40 dias após a primovacinação. A resposta vacinal do grupo 4, 40 dias após o reforço, foi de $1,8 \mathrm{UI} / \mathrm{mL}$, superior ao Grupo 3 que foi de $0,2 \mathrm{UI} / \mathrm{mL}$. Portanto, no esquema proposto, o uso de colostro não induziu a imunização passiva dos cabritos. No entanto, a primovacinação e reforço 40 dias após desencadearam níveis de anticorpos considerados satisfatórios.

TERMOS DE INDEXAÇÃO: Clostridium perfringens tipo D, caprino, enterotoxemia, estratégias de imunoprofilaxia, colostro, vacina.

\section{INTRODUCTION}

Enterotoxemia caused by Clostridium perfringens type D (pulpy kidney disease) is a disease of great economical and sanitary importance for sheep and goat farming worldwide (Niilo 1980, Kriek et al. 1994), and is probably the most important cause of sudden death in goats of different ages. In sheep, the disease is 
caused by epsilon toxin, an important toxin produced by $C$. perfringens type $\mathrm{D}$ (Niilo 1980), and it is believed that the same toxin is responsible for the disease in goats (Smith \& Sherman 1994).

Several factors have been cited as predisposing to the occurrence of pulpy kidney disease, with the most important including sudden dietary changes and a reduction in intestinal transit (Smith \& Sherman 1994). Under experimental conditions, the disease can be induced in goats by the intraduodenal infusion of whole cultures of $C$. perfringens type D (Uzal \& Kelly 1998a). The symptoms and some lesions of the disease have been reproduced in goats by the intravenous injection of $C$. perfringens type D epsilon toxin (Uzal \& Kelly 1997).

The persistence of $C$. perfringens in the environment is the result of previous cases of enterotoxemia or of the constant fecal contamination by various animal species that harbor the microorganism as part of their normal intestinal flora (Niilo 1986, Smith \& Sherman 1994). Normally, epsilon toxin can be produced in small amounts in the intestine of animals carrying $C$. perfringens type $\mathrm{D}$; in this circumstance, the toxin does not cause any deleterious effect and stimulates the formation of antibodies. This is observed in unvaccinated herds in which up to $54 \%$ of the animals present serum epsilon antitoxin antibodies (Blackwell et al. 1983).

Two measures are emphasized as being of great importance in the prophylaxis against enterotoxemia: vaccination of all animals (Uzal 1997, Uzal \& Kelly 1999) and adequate nutritional management. Since no enterotoxemia vaccine produced specifically for goats is available commercially, polyvalent vaccines produced for sheep and/or cattle are generally used (Blackwell et al. 1983).

Sheep are protected against the disease when vaccines of high immunogenic power and adequate immunization strategies are used (Jansen 1960) and remain protected for a year when a booster dose is applied 28-42 days after first vaccination (Uzal et al. 1998a). In goats, however, conventional vaccination produces lower and shorter lived titers than in sheep (Blackwell et al. 1983), and the animals require booster doses every 3 or 4 months throughout their life after first double vaccination (Uzal \& Kelly 1999).

Separation of neonatal goats from their mothers immediately after birth and the use of thermally treated homologous colostrum, or even heterologous bovine colostrum, are recommended for industrial herds as a prophylactic measure against caprine arthritis encephalitis. However, no data exist regarding the use of bovine colostrum to prevent enterotoxemia in goats.

The objective of the present study was to serologically evaluate passive and active immunization strategies against enterotoxemia caused by $C$. perfringens type $\mathrm{D}$ in young goats using colostrum from vaccinated cows in combination with an experimental monovalent vaccine containing epsilon toxoid.

\section{MATERIALS AND METHODS}

Eighteen pluriparous Holstein cows of approximately 4-5 years of age without a history of vaccination against clostridial diseases were used as donors of colostrum for neonatal goats. In addition, 64 Saanen and
Alpine young goats of both sexes, ranging in age from birth to 7 months, born to dams without a history of vaccination against enterotoxemia but with a history of the occurrence of the disease in the herd during previous years were studied.

The experimental monovalent vaccine was provided for the experiment and contained Clostridium perfringens type D epsilon toxoid in aluminum hydroxide as adjuvant. The potency of the vaccine had been previously determined in rabbits using a modification of the technique described by the European Pharmacopoeia (1993). Thus, serum titers in rabbits were assayed by ELISA (Uzal et al. 1997). The median of serum titers determined by ELISA in rabbits inoculated with the vaccine was $1.58 \mathrm{IU} / \mathrm{ml}$.

Ten of the 18 cows used received the first vaccine dose 2 months before calving and a booster dose 26 days after first vaccination. The vaccine was administered subcutaneously in a volume of $2.0 \mathrm{~mL} /$ dose. The other 8 animals were not vaccinated. Colostrum was obtained from the cows during the first two postpartum milkings, with the first milking being performed 4-8 hours after calving and the second $12-20$ hours after the first. The colostrum was frozen at $-20^{\circ} \mathrm{C}$ until the time of use.

The neonatal goats were separated from their mothers immediately after birth to prevent the ingestion of maternal colostrum. Each animal then received four administrations of colostrum previously thawed and heated in a water bath to $36^{\circ} \mathrm{C}$ in a maximum volume of $280 \mathrm{ml} / \mathrm{animal} / \mathrm{suckling}$ period. The first suckling was performed 3-6 hours after birth. The next sucklings were performed at intervals of 5- 6 hours. After the period of colostrum ingestion, the animals were fed commercial milk formula (Sprayfo Blue, Sloten, The Netherlands) up to 50 days of age and then started to receive concentrated ration (Gênesis, Socil) ad libitum until the end of the experiment.

The 64 young goats were divided into four groups. Group $1(n=15)$ received colostrum obtained from unvaccinated cows and no vaccine was applied. The 49 goats of the other three groups received colostrum derived from vaccinated cows. Group $2(n=18)$ received no vaccine, Group $3(n=15)$ received one vaccine dose at 80 days of age, and Group $4(n=16)$ was vaccinated at 80 days of age and received a booster dose 40 days after the first vaccination (Table 1).

Blood was collected by puncture of the jugular vein from cows 60 and 34 days before calving and after calving, and from goats at 3, 80, 120 and 160 days of age. Serum was stored at $-20^{\circ} \mathrm{C}$ until the time of the serological tests.

An indirect ELISA (ELISA-I) was used for the detection of antibodies against epsilon toxin and titers are reported as international units per milliliter (IU/ml) (Uzal et al. 1997). A value of $0.25 \mathrm{IU} / \mathrm{ml}$ was arbitrarily adopted as the minimum protective threshold (Uzal \& Kelly 1998b). Purified epsilon toxin diluted in carbonate buffer, $\mathrm{pH} 9.4$, was used as antigen in the indirect enzyme immunoassay for sensitization of the

Table 1. Passive and active immunization scheme against caprine enterotoxemia caused by epsilon toxin using heterologous colostrum and vaccination in young goats

\begin{tabular}{cccccc}
\hline $\begin{array}{c}\text { Group Number of } \\
\text { animals }\end{array}$ & $\begin{array}{c}\text { Type of colostrum } \\
\text { Unvaccinated cow }\end{array}$ & \multicolumn{2}{c}{$\begin{array}{c}\text { Vaccination } \\
\text { 1st dose } \\
(80)^{\mathrm{b}}\end{array}$} & $\begin{array}{c}\text { 2nd dose } \\
(120)^{\mathrm{b}}\end{array}$ \\
\hline 1 & 15 & $\mathrm{X}^{\mathrm{a}}$ & - & - & - \\
2 & 18 & - & $\mathrm{X}$ & - & - \\
3 & 15 & - & $\mathrm{X}$ & $\mathrm{X}$ & - \\
4 & 16 & - & $\mathrm{X}$ & $\mathrm{X}$ & $\mathrm{X}$ \\
\hline
\end{tabular}

a $\mathrm{X}=$ activity performed

b 80 and $120=80$ and 120 days of life, respectively. 
plates (Uzal et al. 1997). Phosphate-buffered saline containing Tween (PBST), pH 7.2, was used for dilution of the sera and conjugate. The plates were washed between steps with PBST, pH 7.4. Hyperimmune serum from goat at a concentration of $672 \mathrm{IU}$ epsilon antitoxin/mL diluted in PBST, pH 7.2, was used as positive control, and serum from a neonatal goat deprived of colostrum was used as negative control. Caprine immunoglobulins were detected using peroxidase-conjugated monoclonal antibody diluted 1:500. The reaction was developed with ABTS diluted in citrate buffer ( $\mathrm{pH} 9.4)$ as chromogen substrate, and the intensity of staining was read at $414 \mathrm{~nm}$ after $20 \mathrm{~min}$ (Uzal et al. 1997b).

Nonparametric tests were employed for statistical analysis using the SAS program (SAS Institute 1997). The median antibody concentration was used since the results showed a wide variation (high standard deviation). Differences were considered to be significant when $\mathrm{P}<0.05$ (Zar 1992).

\section{RESULTS}

At 60 days before calving, the median serum antibody titer was 0.12 and $0.54 \mathrm{IU} / \mathrm{ml}$ in unvaccinated and vaccinated cows, respectively. After calving, the median titers were 0.79 and 1.01 $\mathrm{IU} / \mathrm{ml}$ for unvaccinated and vaccinated cows, respectively.

The median serum antibody concentration ranged from $0.036-0.106 \mathrm{IU} / \mathrm{mL}$ in all goats 3 days after the ingestion of heterologous colostrums (Table 2). Thus, all animals presented antibody levels below the protective threshold arbitrarily fixed at $0.25 \mathrm{IU} / \mathrm{ml}$.
At 80 days of age, median serum antibody titers of the young goats ranged from $0.085-0.095 \mathrm{IU} / \mathrm{ml}$, and thus continued below the protective threshold.

Analysis of serum samples obtained after 120 days showed median antibody concentrations below the protective threshold for animals from Groups 1 and 2, with values of 0.036 and 0.065 $\mathrm{IU} / \mathrm{ml}$, respectively (Table 2). However, serum antibody titers of 0.685 and $1.180 \mathrm{IU} / \mathrm{ml}$ were observed for animals from groups 3 and 4 , respectively, at 120 days. As shown in Table $3,80 \%$ of Group 3 animals and $80 \%$ of Group 4 animals presented protective antibody titers.

In serum samples collected at day 160, median titers of 0.102 and $0.096 \mathrm{IU} / \mathrm{ml}$ were observed for animals from Groups 1 and 2 , whereas animals from Groups 3 and 4 presented titers ranging from 0.229 to $1.861 \mathrm{IU} / \mathrm{ml}$. Thus, $57 \%$ of Group 3 animals and $87 \%$ of Group 4 animals had antibody titers arbitrarily defined as protective (Table 3, Fig.1).

\section{DISCUSSION}

In the goat-farming industry, effective sanitary programs, together with adequate nutritional management, should be adopted specifically to prevent diseases.

Enterotoxemia is a disease that causes large economical losses in goat farming. Vaccination is the main prophylactic measure used to reduce losses or minimize the severity of the disease. However, no vaccines against enterotoxemia formulated and

Table 2. Mean, standard deviation and median antibody titers $(\mathrm{IU} / \mathrm{ml})$ determined by ELISA-I in serum samples of young goats submitted to various immunization schemes according to day of collection

\begin{tabular}{cccccc}
\hline Group & & \multicolumn{5}{c}{ Day } \\
\cline { 3 - 6 } & & 3 & 80 & 120 & 160 \\
\hline \multirow{2}{*}{1} & $\mathrm{x} \pm \mathrm{sd}$ & $0.104 \pm 0.060$ & $0.087 \pm 0.011$ & $0.015 \pm 0.028$ & $0.111 \pm 0.027$ \\
& median & $0.089 \mathrm{a}$ & $0.085 \mathrm{a}$ & $0.036 \mathrm{~b}$ & $0.102 \mathrm{a}$ \\
2 & $\mathrm{x} \pm \mathrm{sd}$ & $0.102 \pm 0.034$ & $0.100 \pm 0.030$ & $0.062 \pm 0.042$ & $0.095 \pm 0.009$ \\
& median & $0.106 \mathrm{a}$ & $0.095 \mathrm{ab}$ & $0.065 \mathrm{~b}$ & $0.096 \mathrm{ab}$ \\
3 & $\mathrm{x} \pm \mathrm{sd}$ & $0.068 \pm 0.042$ & $0.100 \pm 0.020$ & $0.898 \pm 0.647$ & $0.400 \pm 0.551$ \\
& median & $0.077 \mathrm{~b}$ & $0.089 \mathrm{~b}$ & $0.685 \mathrm{a}$ & $0.229 \mathrm{a}$ \\
4 & $\mathrm{x} \pm \mathrm{sd}$ & $0.033 \pm 0.009$ & $0.106 \pm 0.029$ & $1.019 \pm 0.574$ & $1.315 \pm 0.915$ \\
& median & $0.036 \mathrm{c}$ & $0.089 \mathrm{bc}$ & $1.180 \mathrm{ab}$ & $1.861 \mathrm{a}$
\end{tabular}

Values followed by the same letters in each group did not differ from one another at the 5\% level of significance.

Table 3. Distribution of the number ( $n$ ) and percentage (\%) of young goats from groups 3 and 4 according to the concentration of antibodies present in serum samples on days $3,80,120$ and 160

\begin{tabular}{cccccc}
\hline \multirow{2}{*}{ Group } & Day & \multicolumn{4}{c}{ Antibody titer $(\mathrm{IU} / \mathrm{ml})$} \\
\cline { 3 - 6 } & & \multicolumn{2}{c}{$<0.25$} & $\mathrm{n}$ & $\%$ \\
\cline { 3 - 6 } & & $\mathrm{n}$ & $\%$ & 0.25 & 0 \\
3 & 3 & 15 & 100 & 0 & 0 \\
$(\mathrm{n}=15)$ & 80 & 15 & 100 & 12 & 80 \\
& 120 & 3 & 20 & 8 & 57 \\
4 & 160 & 6 & 43 & 0 & 0 \\
$(\mathrm{n}=16)$ & 3 & 15 & 100 & 0 & 0 \\
& 80 & 25 & 100 & 12 & 80 \\
& 120 & 3 & 20 & 13 & 87
\end{tabular}

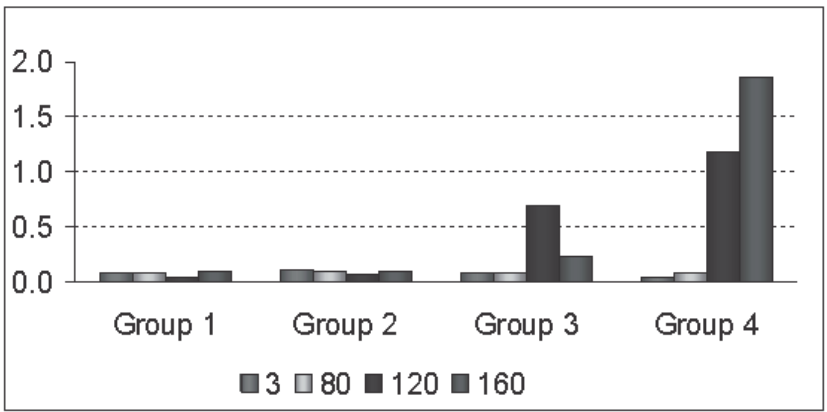

Fig.1. Graphic representation of the median epsilon antitoxin antibody titers $(\mathrm{IU} / \mathrm{ml})$ determined by ELISA in each group of young goats according to day of serum collection. 
developed specifically to protect goats are available (Blackwell et al. 1983, Uzal 1997).

In industrial goat farms with a high prevalence of animals serologically positive for the caprine arthritis encephalitis virus, for which high production rates are desired, passive immunization of neonatal goats with homologous colostrum shows practical and sanitary difficulties. We therefore evaluated the passive immunization of goats against the enterotoxemia challenge during the first weeks of life using heterologous colostrum obtained from cows in combination with an active immunization strategy employing one or two vaccine doses. A literature review did not identify any study regarding the transfer of passive immunity against enterotoxemia through the use of heterologous colostrum in neonatal goats.

Uzal \& Kelly (1998b) established a minimum antibody level of $0.25 \mathrm{IU} / \mathrm{ml}$ as necessary to protect goats against enterotoxemia. In young goats from Group 1 which received colostrum from unvaccinated cows, serum antibody levels were $0.104 \pm 0.060$ $\mathrm{IU} / \mathrm{ml}$ on day 3 . In Groups 2, 3 and 4, antibodies titers in samples collected on day 3 were $0.102 \pm 0.034,0.068 \pm 0.042$ and $0.033 \pm 0 ., 009 \mathrm{IU} / \mathrm{ml}$, respectively, not reaching a sufficient magnitude to eventually protect the newborns against the challenge of Clostridium perfringens type D epsilon toxin. However, it should be mentioned that the immunization scheme used for the cows and the low immunogenic power of the vaccine resulted in a low antibody production in colostrum, emphasizing the need for a vaccine formulation with a higher immunogenic power:

On the other hand, it is also possible that the colostrum contained a good amount of antibodies although they were not detected in blood serum. For some reason, the goat kids did not absorb these antibodies or the antibodies were absorbed but not detected in neonatal goat serum, considering that in the present study an anti-goat conjugate was used in the ELISA-I tests which should lead to a cross-reaction but not necessarily a complete one.

All young goats from Groups 1 and 2 presented antibody titers below the protective threshold at all sampling times. However, protective titers were observed in some animals from Groups 3 and 4 at days 120 and 160 after active immunization. In Group 4 animals, the titers were higher and lasted longer when compared to Group 3 animals. These results agree with those reported by Uzal et al.1998 and Uzal \& Kelly 1999.

A decrease in antibody titers was observed in Group 3 animals at 160 days, in agreement with previous reports indicating that goats require a first double vaccination dose (Jansen 1967, Smith \& Sherman 1994, Uzal \& Kelly 1999).

Furthermore, a marked variation was observed in the individual immune response, a fact also reported by other investigators (Jansen 1967, Blackwell et al. 1983, Green et al. 1987, Uzal \& Kelly 1998a).

Regarding the regimen proposed here, passive immunization of goat kids using heterologous colostrum obtained from cows at the end of gestation was considered to be unsatisfactory. However, immunization of young goats with two initial vaccine doses yielded good results, which were superior to those obtained with the simple immunization scheme.

Acknowledgments.- This work was supported by grants of the "Fundação de Amparo à Pesquisa do Estado de São Paulo", Fapesp.

\section{REFERENCES}

Blackwell T.E., Butler D.G. \& Bell J.A. 1983. Enterotoxaemia in goat: The humoral response and local tissue reaction following vaccination with two different bacterin-toxoids. Can. J. Comp. Path. Med. 47:127-132.

European Pharmacopoeia 1993. Vaccinum Clostridii perfringentis ad usum veterinarium, p.363. 2nd ed. Sant Ruffine, Maisonneuve.

Green D.S., Green M.J., Hillyer M.J., Morgan K.L. 1987. Injection site reactions and antibody responses in sheep and goats after the use of multivalent clostridial vaccines. Vet. Rec. 120(2):435-439.

Jansen B.C. 1960. The experimental reproduction of pulpy kidney disease. J. South Afric. Vet. Med. Assoc. 31:205-208.

Jansen B.C. 1967. The duration of immunity of pulpy kidney disease of sheep. Onderstepoort J. Vet. Res. 34:333-344.

Kriek N.P.J., Odendaal M.W., Hunter P. 1994. Clostridium perfringens type D enterotoxaemia, p.1314-1344. In: Coetzer J.A.W., Thomson G. R. \& Tustin R.C. (ed.) Infectious Diseases of Livestock with Special Reference to Southern Africa, Oxford University Press, Cape Town.

Niilo L. 1980. Clostridium perfringens in animal disease: A review of current knowledge. Can. Vet. J. 21(5):141-148.

Niilo L. 1986. Enterotoxaemia Clostridium perfringens, p.206-214. In: Gyles C.L. \& Thoen C.O. (ed.) Pathogenesis of Bacterial Infections in Animals. Iowa State University Press, Ames.

Sas Institute. 1997. Sas/stas software: changes and enhancements though release 6.12. Statistical Analysis System Institute. 1167p

Smith M.C. \& Sherman D.M. 1994. Enterotoxemia, p.289-305. In: Smith M.C. \& Sherman D.M. (ed.) Goat Medicine. Lea \& Febiger, Pennsylvania. $620 \mathrm{p}$

Uzal F.A. 1997. Studies on enterotoxaemia in goats. Thesis, Division of Veterinary Pathobiology, School of Veterinary Science, University of Queensland, Australia. 164 p.

Uzal F.A. \& Kelly W.R. 1997. Effects of intravenous administration of Clostridium perfringens type D epsilon toxin on young an lambs. J. Comp. Path. 116:63-71.

Uzal F.A. \& Kelly W.R. 1998a. Experimental Clostridium perfringens type D enterotoxaemia in goats. Vet. Path. 32(2):132-140.

Uzal F.A. \& Kelly W.R. 1998b. Protection of goats against experimental enterotoxaemia by vaccination with Clostridium perfringens type D epsilon toxoid. Vet. Rec. 142(26):722-725.

Uzal F.A. \& Kelly W.R. 1999. Serum antibody responses to a Clostridium perfringens epsilon toxoid vaccine in goats. Anaerobe 5:287-289.

Uzal F.A., Nielsen K. \& Kelly W.R. 1997. Detection of Clostridium perfringens type D epsilon antitoxin in serum of goats by competitive and indirect ELISA. Vet. Microb. 51:223-231.

Uzal F.A., Bodero D.A., Kelly W.R. \& Nielsen K. 1998. Variability of serum antibody responses of goat kids to a commercial Clostridium perfringens epsilon toxoid vaccine. Vet. Rec. 143(17):472-474.

Zar J.H. 1992. Bioestatistical Analysis. 4th ed. Prentice-Hall, New Jersey. $920 \mathrm{p}$. 